\title{
Impact of Rewards on Employee Performance: A Case of Indian Oil Corporation, Patna Region
}

\author{
Rashmi Ranjan ${ }^{1,}$ Dr. Umesh Mishra ${ }^{2}$ \\ ${ }^{1}$ Senior Research Fellow, Department of Applied Economics \& Commerce, Patna University, Patna, India \\ ${ }^{2}$ Professor, Head \& Director, Department of Applied Economics \& Commerce, Patna University, Patna, India
}

\begin{abstract}
Today's business environment is very dynamic. Competition is hitting up everywhere and to remain relevant in this scenario an organization must have compatible and motivated workforce who can give their best to the organization even in difficult situations .Reward system is an important tool for organization to motivate its employees. This study aims to see the impact of rewards on employee performance of Indian Oil Corporation, Patna region. The study measure the impact of rewards (Intrinsic and Extrinsic) on performance of employee. The respondents were the employees at managerial level and total numbers were 102. Descriptive statistics based frequency tables and graphs were used in the study to provide information on demographic variables. The results are investigated in terms of descriptive statistics followed by inferential statistics on the variables. A total of 115 questionnaires were distributed to employees of the Indian Oil Corporation and a total of 102 employees completed the questionnaire properly. The result indicate that there is a statistical significant relationship between all of the independent variables with dependent variables employee work performance and all the independent variables have a positive influence on employee work performance.
\end{abstract}

Keywords: Rewards, Intrinsic rewards, extrinsic rewards, Employees' performance.

\section{Introduction}

"Reward is the benefits that arise from performing a task, rendering a service or discharging a responsibility"[1]. Reward is one of the important tools for organization to motivate its employees at workplace. In present competitive business scenario, every organization needs to have competent and motivated human resource, so that organization can sustain in the market. Human Resource is one of the most important factors of production. The world has been changing fast now a days. Competition is hitting up. New products, new technologies, new processes, new entrants, new substitutes are hitting the market regularly. In order to survive, corporate are virtually compelled to economize on every fronts- go after modern technology, restructure operations, explore new markets, find new use of existing products, innovate, experiment and find new ways of living and most importantly use of human resource productively. It is therefore important for a company to find out what motivates its employees so that employees can give their best to the organization. Employees will give their maximum to their organization when they feel that their efforts will be rewarded by the management. Therefore reward management is one of the important functions of Human Resource Management for attracting and retaining competent employees as well as facilitating them to improve their performance through motivation. "Motivation is an accumulation of different processes which influence and direct our behavior to achieve some specific goals"[ 2 ].

Reward includes systems, practices and programs which influence the actions of employees. The aim of reward system is to provide a systematic way to deliver positive consequences. "Fundamental purpose is to provide positive consequences for contribution to desired performance"[ 3 ]. "The only way employees will fulfill the employers dream is to share in their dream"[ 4 ]. Reward system is an important mechanism that makes it happen. Employers can include recognition, bonuses, promotions, challenging assignment, or a simple thank you to motivate their employees. When employees are rewarded, they get work done and employers will get more than their expectations. Thus employees surpass their target or exceed their performance standard they should be rewarded as a way of motivating them. Motivated employees are assets for organization.

\section{Review Of Literature}

Employees do not work for free. The notion of rewarding employees for " a job well done" has existed since early 19th century when piece work system were implemented first. These piece rate systems evolved the traditional merit program. Performance based rewards emerged in 1990's when both public and private sectors began to lose their faith in the traditional merit system of reward. "The primary focus of organizational reward and recognition programs is to define the reward schemes and communicate this in a manner that employees clearly understand the link between reward and performance" [ 5 ].

Rewards that an individual receives are very much a part of his/her motivation. Several literatures have suggested that rewards affect the satisfaction of an employee, which directly influence his/her performance. To 
find the impact of rewards on organizational goal, a research was initiated in UK by Macaulay et al. (2001). Researcher concluded that rewards have great influence on employee's motivation and performance. When employees show high levels of performance, organizations automatically direct towards goal attainment [ 6 ].

A research was conducted on central bank of Nigeria, Abuja [7] to examine the relationship between rewards and employee performance. The finding of the study was that there is existence of strong and significant relationship between extrinsic rewards and performance of employee while the relationship between intrinsic rewards and employee performance was insignificant. Employees of central bank of Nigeria were more motivated to perform by extrinsic financial rewards. Researchers concluded that organization must carefully develop reward structure because rewards affect employee's motivation level and this affect employee's level of performance. A study carried out by Jibowo,7 on the effect of motivators and hygiene factors on job performance among a group of 75 agricultural extension workers in Nigeria. The study supports the influence of motivators/hygiene factors on job performance. In another study conducted by Centers and Bugental (1970), based on Hertzberg two factors theory of motivation, i.e. hygiene factors and motivators. They used a sample of 692 subjects to test the validity of the two factor theory. It was found that at higher occupational level "motivators" or intrinsic job factors were more valued, while at lower occupational levels "hygiene factors" or extrinsic job factors were more valued. They concluded that an organization that satisfies both extrinsic and intrinsic factors of employees could get the best out of them [ 8 ].

Many studies in creativity literature have shown that a firm's reward system plays a critical role in motivating employees to perform creatively. In an effort to stimulate employees' creativity, many managers have used extrinsic rewards to motivate their employees. While empirical research has also shown that extrinsic rewards help to enhance individuals' creative performance. The literature is still divided when it comes to its effect on individuals' creativity [ 9 ]. Azasu (2009) in his "Principal - agency" theory suggested that "most people are opportunist and are always motivated through monetary rewards, while the socio- economic theorist argue that people are neither inclined towards monetary rewards nor they do have a homogeneous approach but might be fascinated by the cocktail of monetary and non- monetary rewards that have the potential to enhance their motivation and commitment"[ 10 ].

A research was conducted which was focused on finding association of rewards with many factors like job satisfaction, employee engagement, motivation and performance. Researchers found that call center employees were more motivated by financial extrinsic rewards than intrinsic rewards. Organization need proper salary, compensation and reward structure in order to reduce turnover costs [11]. A research had been done in Addis Ababa hospital. Rewards are taken as independent variable and motivation as dependent variable. Researchers tried to explore the relation between these variables. Results showed that effect of rewards on employee motivation is strong [ 12 ].

A study was conducted by M.O.Agwu ( 2013 ) on impact of fair reward system on employees' job performance in Nigerian Agip Oil Company Limited. The purpose of the study was to ascertain the impact of fair reward system on employees' performance. This study was based on Adams Equity Theory of motivation which states that the "employees expect fairness when being rewarded for work done; people become dissatisfied, reduce input or seek improvement whenever they feel their inputs are not being fairly rewarded." Fairness is based on perceived market norms. Employees consider whether management has treated them fairly, when they look at what they received for the effort they have made. The result indicated that the implementation of fair reward system improved employee's job performance and reduced rate of industrial action [13].

Serena, et.al (2012) have made an attempt to examine the relationship between rewards and employees job performance in Commercial Bank of Bangladesh. An empirical study has done for this purpose. Researchers also wanted to know the relationship between extrinsic rewards and intrinsic rewards. The result indicated that there was a statistical significant relationship among all of the independent variables with dependent variables employees $^{\text {ee }}$ performance and intrinsic and extrinsic rewards both have a positive influence on job performance on the employees of Commercial Bank of Bangladesh [14].

An empirical study was conducted by Sussane \& Michael to assess the impact of non-material awards on work performance. A field experiment was conducted in collaboration with the Swiss division of the international NGO the Hunger Project (THP). Their result showed that subjects in the award group perform significantly better than the subjects control group, where no awards were given. Hence, there was a strong evidence for the important role of awards in firms and organization [15].

"Cash bonus is another form of reward that organization uses to reward employees for exemplary performance that is if they have performed higher or exceed their set targets, this hence makes them eligible". In this concern a research conducted in Kenya Power and Lighting Company (KPLC), researchers tried to assess the impact of cash bonus on employees job performance. KPLC is an organization that offers essential energy services that support other sectors of the economy. The findings of the study showed that cash bonus have no effect on employees performance. This is because those who received cash bonus and those who did not agree that the cash bonus affects their performance the same [16]. 
An empirical investigation has been done by researchers in Technical Education Authority of Pakistan to analyze the relationship between rewards and performance. Results shown that extrinsic rewards do not have much substantial influence on performance and it was also interesting and notable that extrinsic and intrinsic rewards have different influences on employees performance. Intrinsic rewards were more influensive on performance than extrinsic rewards in Technical Education Authority of Pakistan [17]. Many researchers (2011) from Pakistan have also put their efforts in exploring area of rewards, motivation and employees job performance. In the study of Zakaria.18 It was reported that employees were happier and internally driven to work when they receive good financial and nonfinancial rewards [18]. In study of Carolia Mikander ( 2010 ), the purpose of researcher was to investigate and analyze how well the current reward system of Motonet-Espoo helps to generate employee work motivation. More specifically it aimed to find out which aspects of the reward system functions well, and which aspects could be further developed and improved in order to increase employee satisfaction. The result revealed how Motonet-Espoo can develop its reward system by including the employees in the decision making process. The research report supports the assumption that a well developed and functional reward system can increase employee motivation and satisfaction [19]. In Indian scenario, a research was conducted to see the impact of rewards on employee engagement and the role of motivation in Retail Store Operations. A case study has been done in Delhi and NCR. The research explored the relationship between rewards and employee engagement by taking intermediate role of motivation in the retail store operation in Delhi. The research findings showed a positive relationship between rewards and motivation. It was also determined that motivation and engagement of employee are moderately correlated [20].

\section{Significance Of The Study}

Organization's performance highly depends on the employee's level of motivation. In present competitive working environment it is important for an organization to find out factors that may motivate its employees. The concern has to develop a suitable reward system with right combination of monetary and nonmonetary rewards. This can boost the employee's motivational level and they can work with more enthusiasm and enhance their commitment towards the organization and the job. The purpose of the study is to investigate and analyze the current reward system of Indian Oil Corporation is to assess that how much it is helpful to motivate its employees. More specifically, it aims to find which aspect of reward system functions well, and which aspects could be further developed and improved in order to increase employees ${ }^{\text {ee }}$ work motivation and satisfaction level. Indian Oil Corporation is a public sector undertaking and got Maharatna status on May 21, 2010. It is No.1 petroleum trading company in the Asia-Pacific region. The driving force behind study is to examine the contribution of the employees in achieving such level of success and became most valued brand in India and to enable the employees of IOCL to give feedback on their motivation and their attitudes towards the reward system that led to increase their commitment to the company.

\section{1- Significance of the Research for the Clientele (Indian Oil Corporation)}

Although Indian Oil Corporation is a leading company in the field of petroleum trading, but there are a number of competitors existing in the environment like, Hindustan Petroleum Corporation Ltd., Bharat Petroleum Corporation Ltd, Reliance petroleum, etc which are trying to become most leading company. Poaching is a very common phenomena in current business environment through which rival companies are trying to attract talented employees of competitors by offering better perks and benefits. Therefore, it is a challenge for the company to retain its talented employees with itself for longer period. This research work will give to IOCL competitive advantage through a feedback about existing reward policy and suggestions to develop a competitive reward system through eye's of employees of IOCL itself.

The objectives of the study are following:

\section{Objectives Of The Study}

- To analyze the reward system of IOCL.

- To study the impact of intrinsic reward on employees performance.

- To study the impact of extrinsic reward on employees performance.

\section{Hypotheses Of The Study}

In order to analyse the impact of independent variable on dependent variables, following hypotheses have been formulated:

Ho: There is no significant impact of extrinsic rewards on employee's job performance.

H1: There is a significant impact of extrinsic rewards on employee's job performance.

Ho: There is no significant impact of intrinsic rewards on employee job performance.

$\mathrm{H} 2$ : There is a significant impact of intrinsic rewards on employee job performance. 


\section{Scope Of The Research Work}

This research work is limited to the employees of the Indian Oil Corporation, Patna region. For the study the employees from executive level and above have been considered as respondent. Because of various constraints, it is not possible to take huge number of respondent.

\section{Theoritical Framework Of The Study}

Vroom in his Expectancy Theory of Motivation, suggested that individuals will choose specific behaviour over other behaviours because they expect the result of that selected behaviour will value to them. Individuals are likely to consider three things when they decide how much effort to put into work; valence, instrumentality and expectancy. All three factors are often referred as 'VIE' and they are considered to influence motivation in a combined manner. Management should therefore attempt to ensure their employees that increase effort will lead to higher performance which will hence lead to valued rewards (Ryan \& Pointan, 2005).

Motivation $($ force $)=\sum$ Valence $\times$ Expectancy

Relationship of the variables for this study is exhibited to the following figure:

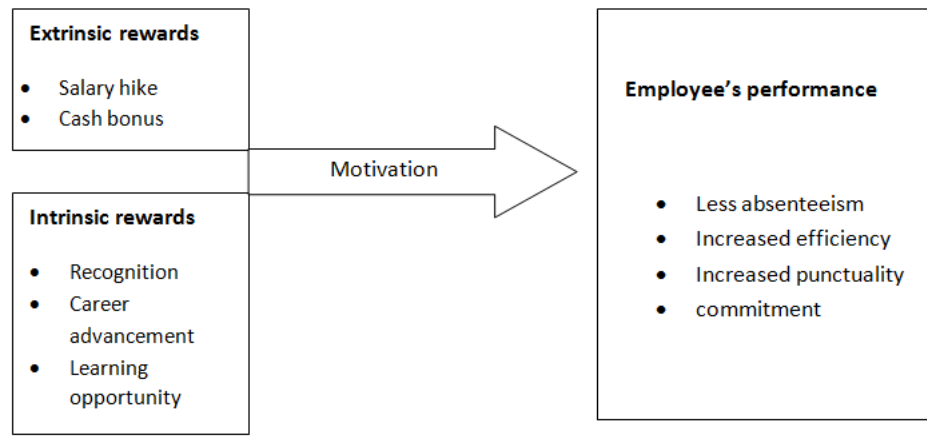

Fig 1: Conceptual framework of research on the relationship of extrinsic and intrinsic reward and employee's performance.

\section{Research Methodology}

This is an empirical study, based on primary data. Structured questionnaire were used for data collection and a census study has been done. The researcher wanted to know whether cash bonus given to employees of IOCL have any impact on performance of the employees. The research has taken an authorization letter from the Department of Applied Economics \& Commerce, Patna University. This study has been done from executive level and above. The total questionnaire were distributed among 115 randomly selected employees. The questionnaire were structured on five points Likert scale with five for strongly agree, four for agree, three for neutral, two for disagree and one for strongly disagree. The respondents were given two weeks to complete the questionnaire. The study considers intrinsic and extrinsic rewards as independent variables. As independent variable, extrinsic rewards includes salary hike and performance bonus. As for the intrinsic rewards, it includes recognition, learning opportunity and challenging work. This study involves employee performance as dependent variable. Performance of the employees was measured on four different parameters i.e. punctuality, efficiency, absenteeism and commitment.

\section{1- Extrinsic reward}

An extrinsic reward is tangible form of reward that is provided to employees after work performance such as pay raise, promotion, cash bonus, etc. These are not inherent to the work itself but emerge from outside the work.

\section{2- Intrinsic reward}

An intrinsic reward emerges from the work performance itself when the work performer experiences sense of accomplishment on doing a good work such as recognition, career advancement, learning opportunity. Intrinsic rewards satisfy employee internally.

\section{1- Demographic profile of the respondents:}

\section{Data Analysis And Interpretation}

The self completion questionnaire was administered to more than 115 respondents. Out of the total distributed questionnaire, 102 completely filled questionnaires have been taken for the analysis. The 102 respondent samples have been described on the basis of their gender, age and educational qualification by the following tables (table 1, $2 \& 3$ ): 


\subsection{1 - Gender distribution of respondents}

Table - 1

\begin{tabular}{|l|l|l|}
\hline Gender & Frequency & Percentage \\
\hline Male & 86 & 84.31 \\
\hline Female & 16 & 15.87 \\
\hline Total & $\mathbf{1 0 2}$ & $\mathbf{1 0 0}$ \\
\hline
\end{tabular}

As per table 1, total of 102 respondents consist of 86 male and 16 female respondents which is $84.31 \%$ and $15.87 \%$ of the total respondents respectively.

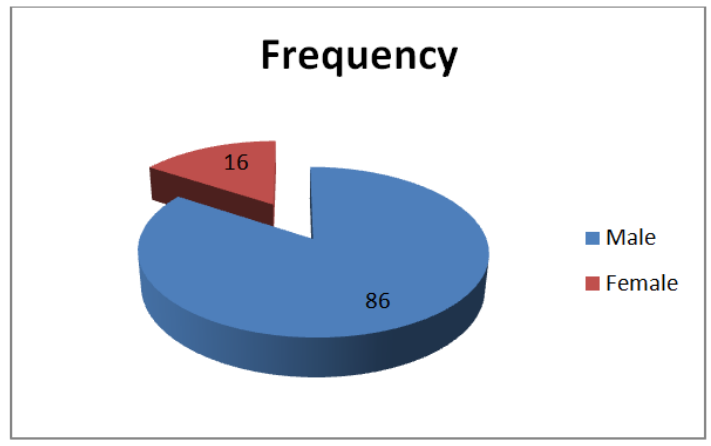

\subsection{2 - Age profile of the respondents}

Table: 2

\begin{tabular}{|l|l|l|}
\hline Age group & Frequency & Percentage \\
\hline $18-28$ years & 06 & 5.88 \\
\hline $29-38$ years & 17 & 16.66 \\
\hline $39-48$ years & 21 & 20.58 \\
\hline $49-58$ years & 53 & 51.96 \\
\hline 59 years and above & 03 & 2.94 \\
\hline Total & $\mathbf{1 0 2}$ & $\mathbf{1 0 0}$ \\
\hline
\end{tabular}

Table no. 2 indicates that out of 102 respondents 6 respondents were in the 18-28 years' age group, 17 were in the 29-38 years' age group, 21 were in the 39-48 years' age group, 53 were in the $49-58$ years' age group and 03 were in the 59 and above years' age group which is $5.88 \%, 16.66 \%, 20.58 \%, 51.96 \%$ and $2.94 \%$ of the total respondents respectively.

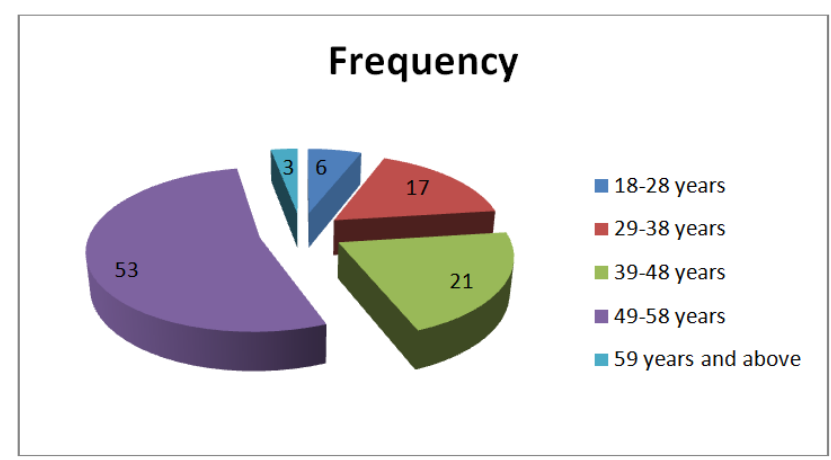

\subsection{3 - Educational profile of the respondents}

\begin{tabular}{|l|l|l|}
\hline Qualification level & Frequency & Percentage \\
\hline Graduate & 27 & 26.47 \\
\hline Post- graduate & 75 & 73.52 \\
\hline Total & $\mathbf{1 0 2}$ & $\mathbf{1 0 0}$ \\
\hline
\end{tabular}

From the table 3 it is clear that 27 respondents were graduate and 75 respondents were post-graduate which was $26.47 \%$ and $73.52 \%$ of the total respondents respectively. 


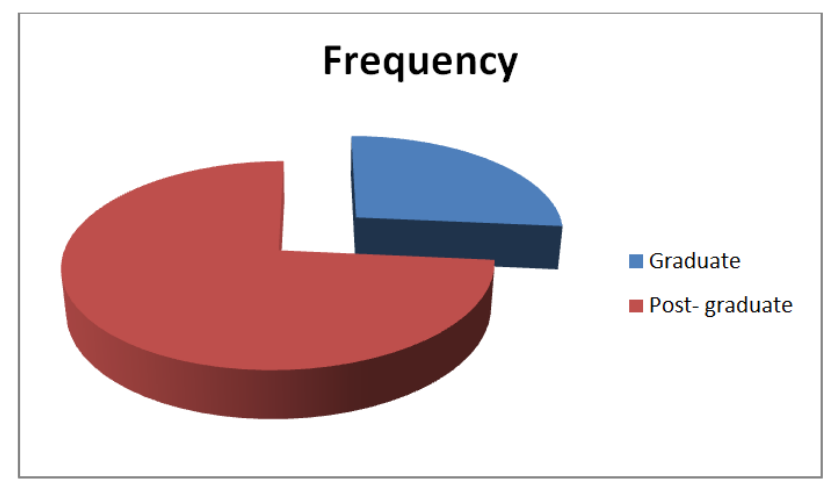

\section{2- Test of hypotheses}

Hypotheses testing have been done by using chi square test to see the impact of extrinsic and intrinsic rewards on the different parameters of performance i.e. punctuality, efficiency, absenteeism and commitment. Chi square test has been done by using SPSS. It has been shown by following table:

Table 4 Reward System encourage them to Perform task Punctually, Cross tabulation

\begin{tabular}{|c|c|c|c|c|c|}
\hline & & & \multicolumn{2}{|c|}{$\begin{array}{l}\text { Encourage them perform their task } \\
\text { punctually }\end{array}$} & \multirow[t]{2}{*}{ Total } \\
\hline & & & Agree & Disagree & \\
\hline \multirow{15}{*}{ Reward System } & \multirow{3}{*}{ Salary Hike } & Count & 75 & 27 & 102 \\
\hline & & Expected Count & 67.4 & 34.6 & 102.0 \\
\hline & & $\%$ within Reward System & $73.5 \%$ & $26.5 \%$ & $100.0 \%$ \\
\hline & \multirow[t]{3}{*}{ Cash Bonus } & Count & 41 & 61 & 102 \\
\hline & & Expected Count & 67.4 & 34.6 & 102.0 \\
\hline & & $\%$ within Reward System & $40.2 \%$ & $59.8 \%$ & $100.0 \%$ \\
\hline & \multirow[t]{3}{*}{ Recognition } & Count & 93 & 9 & 102 \\
\hline & & Expected Count & 67.4 & 34.6 & 102.0 \\
\hline & & $\%$ within Reward System & $91.2 \%$ & $8.8 \%$ & $100.0 \%$ \\
\hline & \multirow{3}{*}{$\begin{array}{c}\text { Career } \\
\text { Advancement }\end{array}$} & Count & 89 & 13 & 102 \\
\hline & & Expected Count & 67.4 & 34.6 & 102.0 \\
\hline & & $\%$ within Reward System & $87.3 \%$ & $12.7 \%$ & $100.0 \%$ \\
\hline & \multirow{3}{*}{$\begin{array}{c}\text { Learning } \\
\text { Opportunity }\end{array}$} & Count & 39 & 63 & 102 \\
\hline & & Expected Count & 67.4 & 34.6 & 102.0 \\
\hline & & $\%$ within Reward System & $38.2 \%$ & $61.8 \%$ & $100.0 \%$ \\
\hline \multirow{3}{*}{\multicolumn{2}{|c|}{ Total }} & Count & 337 & 173 & 510 \\
\hline & & Expected Count & 337.0 & 173.0 & 510.0 \\
\hline & & $\%$ within Reward System & $66.1 \%$ & $33.9 \%$ & $100.0 \%$ \\
\hline
\end{tabular}

Table- 4.1 Chi-Square Tests

\begin{tabular}{|l|c|c|c|}
\hline & Value & df & Sig. (2 tailed) \\
\hline Pearson Chi-Square & $117.359^{\mathrm{a}}$ & 4 & .000 \\
\hline Likelihood Ratio & 123.562 & 4 & .000 \\
\hline Linear-by-Linear Association & 2.514 & 1 & .113 \\
\hline N of Valid Cases & 510 & & \\
\hline a. 0 cells (.0\%) have expected count less than 5. The minimum expected count is 34.60. \\
\hline
\end{tabular}

Table 4.1 shows that value of chi-square is 117.359. the table value of chi-square for 4 degree of freedom at 5 percent level of significance is 9.488. The calculated chi-square value is much higher than this table and hence the result shown that both intrinsic and extrinsic rewards have a significant impact on punctuality.

Table - 5 Reward System motivate them to finsh their task within standard time ( efficiency), Cross tabulation

\begin{tabular}{|c|c|c|c|c|c|}
\hline & & & \multicolumn{2}{|c|}{$\begin{array}{l}\text { Motivate them to finish their } \\
\text { task within standard time }\end{array}$} & \multirow[t]{2}{*}{ Total } \\
\hline & & & Agree & Disagree & \\
\hline \multirow[t]{5}{*}{ Reward System } & \multirow[t]{3}{*}{ Salary Hike } & Count & 67 & 35 & 102 \\
\hline & & Expected Count & 73.4 & 28.6 & 102.0 \\
\hline & & $\%$ within Reward System & $65.7 \%$ & $34.3 \%$ & $100.0 \%$ \\
\hline & \multirow[t]{2}{*}{ Cash Bonus } & Count & 43 & 59 & 102 \\
\hline & & Expected Count & 73.4 & 28.6 & 102.0 \\
\hline
\end{tabular}


Impact of Rewards on Employee Performance: A Case of Indian Oil Corporation, Patna Region

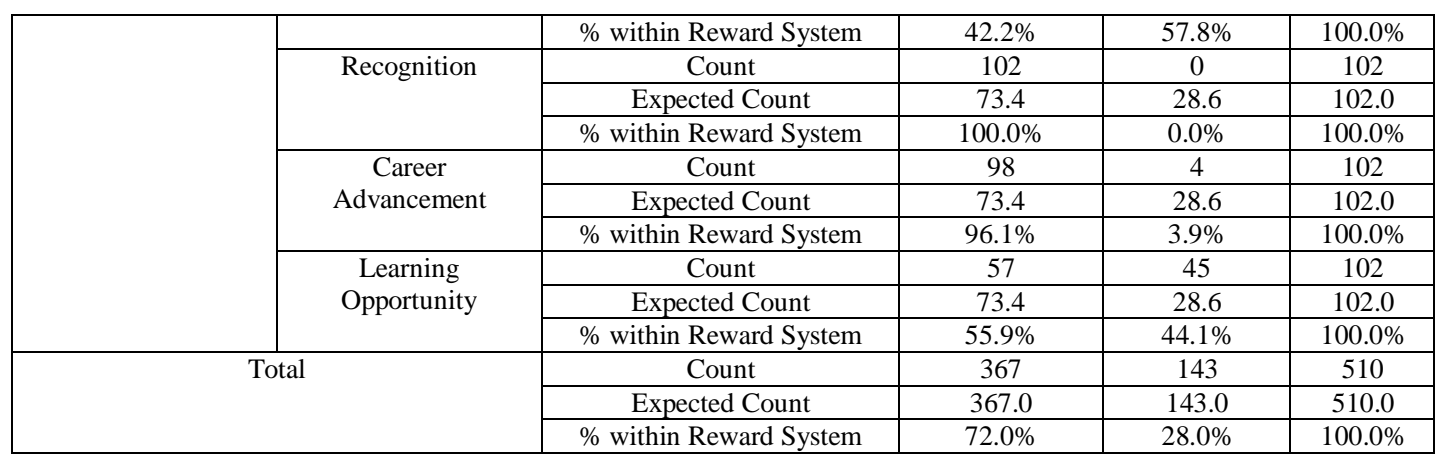

Table - 5.1 Chi-Square Tests

\begin{tabular}{|l|c|c|r|}
\hline & Value & Df & Sig. (2 tailed) \\
\hline Pearson Chi-Square & $129.111^{\mathrm{a}}$ & 4 & .000 \\
\hline Likelihood Ratio & 161.379 & 4 & .000 \\
\hline Linear-by-Linear Association & 5.940 & 1 & .015 \\
\hline N of Valid Cases & 510 & & \\
\hline a. 0 cells (.0\%) have expected count less than 5. The minimum expected count is 28.60. \\
\hline
\end{tabular}

Table 5.1 shows that value of chi-square is 129.111 . The table value of chi-square for 4 degree of freedom at 5 percent level of significance is 9.488 . The calculated chi-square value is much higher than this table and hence the result shown that both intrinsic and extrinsic rewards have a significant impact on efficiency.

Table - 6 Reward System motivate them to take minimum leave (absenteeism), Cross tabulation

\begin{tabular}{|c|c|c|c|c|c|}
\hline & & & \multicolumn{2}{|c|}{ Motivate to Take Minimum Leave } & \multirow[t]{2}{*}{ Total } \\
\hline & & & Agree & Disagree & \\
\hline \multirow[t]{15}{*}{ Reward System } & \multirow[t]{3}{*}{ Salary Hike } & Count & 44 & 58 & 102 \\
\hline & & Expected Count & 71.4 & 30.6 & 102.0 \\
\hline & & $\%$ within Reward System & $43.1 \%$ & $56.9 \%$ & $100.0 \%$ \\
\hline & \multirow[t]{3}{*}{ Cash Bonus } & Count & 59 & 43 & 102 \\
\hline & & Expected Count & 71.4 & 30.6 & 102.0 \\
\hline & & $\%$ within Reward System & $57.8 \%$ & $42.2 \%$ & $100.0 \%$ \\
\hline & \multirow[t]{3}{*}{ Recognition } & Count & 99 & 3 & 102 \\
\hline & & Expected Count & 71.4 & 30.6 & 102.0 \\
\hline & & $\%$ within Reward System & $97.1 \%$ & $2.9 \%$ & $100.0 \%$ \\
\hline & \multirow{3}{*}{$\begin{array}{c}\text { Career } \\
\text { Advancement }\end{array}$} & Count & 87 & 15 & 102 \\
\hline & & Expected Count & 71.4 & 30.6 & 102.0 \\
\hline & & $\%$ within Reward System & $85.3 \%$ & $14.7 \%$ & $100.0 \%$ \\
\hline & \multirow{3}{*}{$\begin{array}{c}\text { Learning } \\
\text { Opportunity }\end{array}$} & Count & 68 & 34 & 102 \\
\hline & & Expected Count & 71.4 & 30.6 & 102.0 \\
\hline & & $\%$ within Reward System & $66.7 \%$ & $33.3 \%$ & $100.0 \%$ \\
\hline \multirow{3}{*}{\multicolumn{2}{|c|}{ Total }} & Count & 357 & 153 & 510 \\
\hline & & Expected Count & 357.0 & 153.0 & 510.0 \\
\hline & & $\%$ within Reward System & $70.0 \%$ & $30.0 \%$ & $100.0 \%$ \\
\hline
\end{tabular}

Table - 6.1 Chi-Square Tests

\begin{tabular}{|l|c|r|r|}
\hline & Value & df & Sig. (2 tailed) \\
\hline Pearson Chi-Square & $89.692^{\mathrm{a}}$ & 4 & .000 \\
\hline Likelihood Ratio & 102.623 & 4 & .000 \\
\hline Linear-by-Linear Association & 26.913 & 1 & .000 \\
\hline N of Valid Cases & 510 & & \\
\hline a. 0 cells (.0\%) have expected count less than 5. The minimum expected count is 30.60. \\
\hline
\end{tabular}

Table 6.1 shows that value of chi-square is 89.111 . The table value of chi-square for 4 degree of freedom at 5 percent level of significance is 9.488 . The calculated chi-square value is much higher than this table and hence the result shown that both intrinsic and extrinsic rewards have a significant impact on absenteeism. 
Table 7 Reward System enhance their commitment towards Job and Org (commitment), Cross tabulation

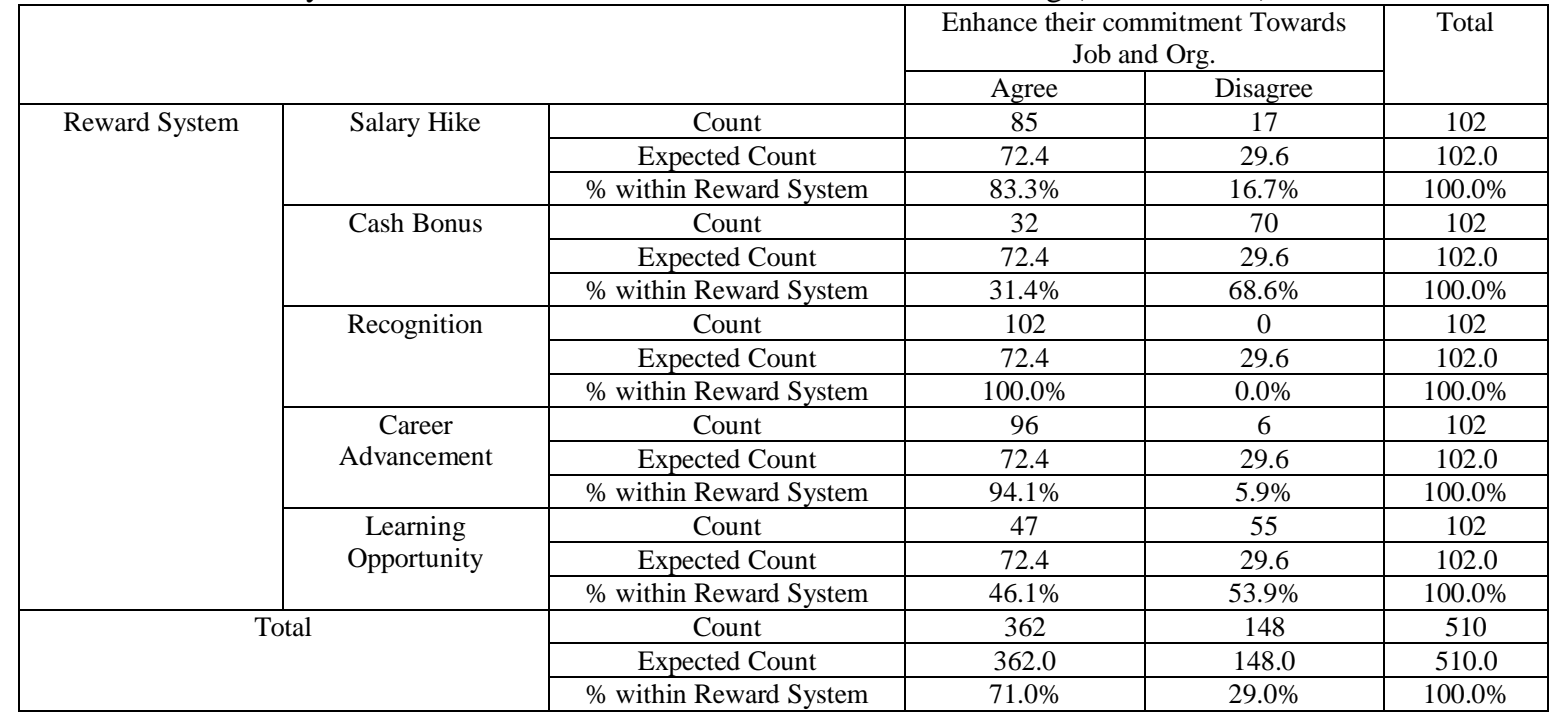

Table - 7.1 Chi-Square Tests

\begin{tabular}{|l|c|c|r|}
\hline & Value & df & Sig. (2 tailed) \\
\hline Pearson Chi-Square & $184.158^{\mathrm{a}}$ & 4 & .000 \\
\hline Likelihood Ratio & 209.149 & 4 & .000 \\
\hline Linear-by-Linear Association & .684 & 1 & .408 \\
\hline N of Valid Cases & 510 & & \\
\hline a. 0 cells (.0\%) have expected count less than 5. The minimum expected count is 29.60. \\
\hline
\end{tabular}

Table 7.1 shows that value of chi-square is 184.158 . The table value of chi-square for 4 degree of freedom at 5 percent level of significance is 9.488 . The calculated chi-square value is much higher than this table and hence the result shown that both intrinsic and extrinsic rewards have a significant impact on commitment.

Table - 8 Summary of hypotheses result

\begin{tabular}{|l|l|l|}
\hline \multicolumn{2}{|c|}{ Hypotheses } & Result \\
\hline H1 & There is significant impact of intrinsic rewards on employee performance & Accepted \\
\hline H2 & There is significant impact of extrinsic rewards on employee performance & Accepted \\
\hline
\end{tabular}

Result on hypotheses shows that both intrinsic and extrinsic rewards have significant impact on employee performance.

\section{Suggestions}

- IOCL is a public sector undertaking (PSU) in India and it has been advocating "One Size Fits All Approach". This also holds true in the case of Indian Oil Corporation Ltd (IOCL). Therefore, cash bonus is linked to Basic plus D.A of the employees. There is possibility that employees working within same pay scale work differently. Someone works may more satisfactory but someone not. In this situation, employees who worked up to more satisfactory level will get same as the employees whose work was less satisfactory. It will create dissatisfaction among the employees. Therefore, reward schemes must be person oriented rather than organization.

- Such organizations are under the immense pressure to adopt various private sectors tools like 360 degree appraisal system, Incentives linked to performance etc to sustain their legitimacy without knowing the compatibility of the tools used. So it is suggested that tools and techniques adopted should be as per the requirements of the organization along with the consent of Human Resource Department rather than adopting it blindly.

- Government should ensure that the reward schemes are more employees oriented rather organization oriented. "A Balanced Approach" or "A Slow Transition" would be a better approach than jumping to them in a fast mode. Government should recommend policies as per the culture and working of public sector undertakings and therefore they ensure that the policies are more employees oriented rather than for organization good only.

- Government should offer a sort of "Cafeteria Approach" where an individual could pick up the tewarde as per their preference. 


\section{Conclusions}

On basis of the above study, we can say that cash bonuses have a positive impact on employee's performance in Indian Oil Corporation Ltd. But many of the employees perceived that it has no positive impact on performance and some of them were neutral. It has seen that many employees were not satisfied with cash reward of the company. According to them bonus has not been fairly distributed among the employees.

\section{Acknowledgements}

Perhaps nothing in the world can be achieved in isolation. Therefore, we need co-operation of others for the effective accomplishment of our objective I do acknowledge that this research is an outcome of constructive support and co-operation of many individuals. First of all I would like to express my deepest gratitude to my supervisor Dr. Umesh Mishra, Professor, for his support, guidance and encouragement.. My special thanks to Mr.R.S.Dahia (General Manager) IOCL, Patna and Mr.J.L Chattopadhyay (Sr. HR Manager) BSO, Patna for allowing me to do this project. I express my special gratitude to Ms. Vipin Kumar (Operation Manager) BSO, Er. Md. Azaharuddin who despite of being very busy, spare their valuable time and experience with me. I would also like to thank all the respondents who provide me valuable information for the research. I express mys gratitude to my all dear research scholars who helped me to in this research work. I am also thankful to staff members of the Department. Last but not the least I am thankful to my family members and almighty for showering their blessing on me.

\section{Books}

[1] Colin pits, Motivating your organization, Ist edition, McGraw Hill International, 1995, P. 187

[2] Baron RA, Behavior in organization, Newyork: Allyn and Bacon 1983

[3] Thomas B.Wilson, Innovative reward systems for the changing workplace. Tata McGraw-Hill, 1995

[4] kotelnikov V, Reward system and reward motivation, 2010

[5] Flynn G. "Is your recognition program understood?" Workforce, 1998

[6] Macaulay, S. and S. Cook, Rewarding service success. Measuring business excellence, 2001

\section{Journal papers}

[7] Jibowo AA. Effect of motivators and hygiene factors on job performance among extension workers in the former western state of Nigeria. The quarterly journal of administration. 1977; 12(1): 45-54

[8] Centers and Bugental (1970), Referenced in Muhammad IQ, Khalid Z, Iqtidar AS. Relationship between rewards and performance in cement industry in Pakistan. Journal of International Academic Research. 2010

[9] Baer M, Oldham GR, Cummings A, Rewarding creativity: When does it really matter? The Leadership Quarterly. 2003; 14(4): 56986

[10] Azasu S. Rewards and performance of Swedish real state firms. Compens. Ben. Rev. 2009; 41(4): 19-28

[11] Malhotra N, Budhwar P, Prowse P. Linking rewards to commitment: Empirical investigations of four UK call centers: Int. J. Hum. Res. manages. 2007; 18(12) 95-127

[12] Negussine N, Relationship between rewards and work motivation: In Addis Ababa hospital. Ethopian journal of health sciences, 2012, 107-112

[13] M. O. Agwu, Impact of fair reward system on employees job performance in Nigerian Agip Oil Company Limited Port - Harcourt, British journal of education, society and behavioural science; 3(1) 47-64, 2013

[14] Serena Aktar, Muhammad Kamruzzaman, Md. Emran Ali. The impact of rewards on employee performance in commercial banks of Bangladesh: An empirical study, IOSR Journal of business and management, 2012, pp 09-15

[15] Sussane Neckermann, Michael Kosfeld. Working for nothing? The effect of non-material awards on employees performance.

[16] W. L. Njanja, R. N. Maina, L. K. Kibet \& Kageni Njagi. Effect of reward on employee performance: A case of Kenya Power and Lighting Company Limited., Nakuru, Kenya. 2013. International journal of business and management

[17] Rashid Saeed, Hafiza Hafsa Nayyab and Rab Nawaz Lodhi. An Empirical Investigation of Rewards and Employee Performance: A Case Study of Technical Education Authority of Pakistan. Middle-East journal of Scientific Research. 2013. Pp-892-898

[18] Zakaria, Z., Z.H. Hussain, N. Noordin and M.Z.Sawal, 2011. The relationship between reward practices and employee performance. An empirical study. International conference on management and artificial intelligence, pp: 142-145

[19] Carolina Mikander. 2010. The impact of reward system on employee motivation in Motonet- Espoo. International Business

[20] Mishra, P. and V. Dixit, 2013. Compensation, Impact of Rewards on Employees Engagement and the role of motivation in Retail Store Operation. A case study of Nelhi and NCR. Tenth AIMS International Conferencen on Management. Pp: 1237-1246 